\title{
Saudi Pre-Service Special Education Teachers' Knowledge and Perceptions Toward Using Computer Technology
}

\author{
Manal M. Alanazy ${ }^{1} \&$ Reem F. Alrusaiyes ${ }^{1}$ \\ ${ }^{1}$ School of Education, King Saud University, Riyadh, Saudi Arabia \\ Correspondence: Manal M. Alanazy, School of Education Technology, King Saud University, Riyadh, Saudi \\ Arabia. E-mail: maalanazy@ksu.edu.sa
}

Received: October 8, 2020

Accepted: November 13, 2020

Online Published: February 24, 2021

doi:10.5539/ies.v14n3p125

URL: https://doi.org/10.5539/ies.v14n3p125

\begin{abstract}
The authors investigated pre-service special education teachers' prior experience in using computers and their perception of the knowledge, and their preparedness toward integrating computer technology in teaching, barriers in integrating computer technology in their teaching practices and the level of confidence teachers gained from using technology applications in teaching. Fifty-eight pre-service special education female teachers from a college of education in Saudi Arabia responded to a needs assessment survey. Most participants had more than eight years of experience in using computers. They reported that they are able to integrate computer technologies in their teaching but acknowledged the need for more training courses. The barriers mentioned were a lack of equipment, lack of practice, and lack of maintenance. The findings of this research reveal that there is a need to intensify or enhance the technology courses in programs that prepare special education teachers and focus on the practical aspects of integrating technology in teaching.
\end{abstract}

Keywords: educational technology, integrating computer technology, perception, pre-service teachers, special education, teachers' programs

\section{Introduction}

The emergence of technology dominates all aspects of our lives. Computer technology continues to rapidly develop with crucial impacts in many fields like medicine, business, industry, and entertainment as well as education. Technology has been applied in various areas of society to help facilitate and enhance the quality of work. In education, technology has a positive impact on learning and teaching methods. When technology is effectively applied and integrated into the classroom, learners will be successful on both a functional and personal basis (Abercrombie, 2016; Sabzian, Gilakjani, \& Sodouri, 2013). The importance of technology in education was reinforced during the COVID-19 pandemic, as many countries rely on computers and mobile devices to continue the educational process while preserving the health of their citizens.

Because computer technology has become such a worldwide cornerstone for improving student performance in all grade levels, Mwalongo (2011) in Tanzania examined teachers' perceptions about the use of information communication technology (ICT) or software in teaching. He found that the use of ICT has been beneficial in making difficult concepts clear, saving time, keeping students active, maintaining traditional education, and facilitating work for teachers. A. W. Bates, T. Bates, and Sangra (2011) reported that the use of instruction technology shifted the classroom environment from being teacher-centered to being student-centered. It also enhanced the students' achievement and their attitudes toward this technology in the primary and secondary classrooms. By integrating technology into the classroom, both students and teachers benefit from computer technology's positive influence (Lam \& Lawrence, 2010). Effective use of technology can boost the development of teaching methodologies and the acquired knowledge of students (Frigaard, 2002; Timucin, 2006).

Nevertheless, technology has been deemed even more important in special education because it facilitates addressing individual needs and simplifying complex concepts (Williams, Jamali, \& Nicholas, 2006). Similarly, Johanson (1998) further supported this function of technology as it enables teachers to create learning activities within an inclusive learning environment where the student with disabilities can learn and play with other students. Further, by integrating technology in special education, positive effects are noted in student motivation, attitudes, achievements, and peer interaction, providing differentiation, representing the content variably, offering 
formative assessment, and endorsing life skills (Adam \& Tatnall, 2017; Anderson \& Putman, 2020; Schofield, 1995). Thus, the consensus among most educators is that some ICT technologies have the potential to enhance the educational, social, and cultural growth of students with disabilities (Girgin, Kurt, \& Odabasi, 2011; Saba, 2009).

Despite the usefulness of merging technology into the education processes, a gap still exists in the understanding of its proper use in the educational environment (Banister \& Ross, 2005; Oliver, Osa, \& Walker, 2012). Making sure teachers understand the usefulness and challenges of technology integration is an essential stage in introducing technology at school, so essential that the lack of this knowledge is an obstacle to the extensive use of technology in the classroom (Anderson \& Putman, 2020; Riasati, Allahyar, \& Tan, 2012). For example, computers and cellphones offer profound new opportunities for focusing and learning, but they can also be distractions to students. Some educators believe that the use of technology in the classroom prevents students from focusing and excelling in their studies (Richtel, 2010). For example, valuable time can be lost "if students spend most of their time picking fonts and colors for multimedia reports instead of planning, writing, and revising their ideas" (National Research Council, 2000, p. 206).

Koc and Bakir (2010) recognized that the experience and ability of pre-service special education teachers to integrate computer technology into their teaching was a positive factor that enhanced their success in their teacher education programs. This prompted them to recommend more studies on pre-service teachers' preparation for using technology in teaching. Years back, Handler, and Pigott (1995) made a similar suggestion, realizing the importance of introducing teacher programs that could prepare a new generation of teachers who can integrate technology in education, especially for students with special needs.

In Saudi Arabia, earlier research on integrating computer technology in special education was divided into three main study groups. The first group focused on the effectiveness of using technology with specific types of disabilities, such as students with intellectual disabilities or learning disabilities (Elsersy, Ibrahim, \& Esayed-Sedeg, 2016; Al Sheha, 2005; Hawsawi, 2002). The second group investigated tools that have been used in the special education field (Alkahtani, 2013). The third group researched the barriers to integrating technology with specific groups of students with special needs (Al-johanin \& Al-zarea, 2014; Hawsawi, 2007). However, few studies have been published regarding pre-service special education teachers' preparation for and perception of using technology in their teaching practice.

This paper reports the results of a survey highlighting the importance of identifying ways to help pre-service special education teachers prepare for efficient and effective use of computer technologies in the classroom. The purpose of this study is to determine the pre-service special education teachers' prior experience in using computers, their perception of the knowledge, and their preparedness toward integrating computer technology in teaching, barriers to integrating computer technology in education, and the level of confidence teachers gained from using technology applications in teaching.

\section{Literature Review}

The terms used to describe disabilities have changed over time: it started with the term handicapped, then disability, and, currently, special needs. All of these terms refer to problems in areas such as cognition, sensation, communication, physical abilities, and emotion, which result in significant learning difficulties. These problems have negative impacts on students' success in a general education classroom, thus the need for special education. According to the General Authority for Statistics reported in 2017, "[t]he survey conducted results indicated that (2.9\%) of Saudi population have disability with extreme difficulty" (2020, phar. 1), which explains the increase of students with special education needs (SENs) in schools in Saudi Arabia. These students are often compelled to drop out of school without the training needed for employment (Posada, Primo, Ferrari, \& Martín-Arribas, 2007). Consequently, the parents of students with special needs often experience high levels of stress, as their children are often unable to participate in regular community activities because of the lack of support from the government and society (Hasselbring \& Glaser, 2000; Weiss, 2002). As a result, there has been a rapid increase in efforts to provide special education to these students and to integrate ICT technology needed to help them gain the skills they need to be productive, wage-earning members of society.

\subsection{ICT Technology with Software Innovation-A Made-to-Order Innovation for SENs}

In education today, inclusive methods and approaches represent a crucial adjustment in teaching and learning. In special education, teachers face more diverse challenges in the classroom than teachers in general education. This means that they need different technologies in their classes to facilitate their teaching processes. Several technologies are available to assist students with special needs, which can increase, maintain, and develop their functional abilities (Edyburn, 2000). These technologies often include hardwares and software applications or 
other tools such as internet websites. In Finland, the following technologies are used in special education: i) assistive technologies, ii) communication technologies, iii) learning software, and iv) concretizing technologies (e.g., educational robotics) (Kärnä-Lina, Pihlainen-Bednarika, Sutinenb, \& Virnesb, 2007, p. 105). Special education students have several needs, and there is no specific software tool or program with the ability to address all their learning needs. For example, a wide range of software tools, such as Proloquo2Go and iComm, supports writing among the various learning abilities (The Masters in Special Education Degree Program Guide, 2020).

Some specialized software can allow students to perform different processes, such as word prediction, planning and organizing, specialized spell checks, speech synthesis, and speech recognition. Various non-technology programs and tools can also help students in mathematics. For example, students can use talking calculators, unique feature calculators, specialized hand-held calculators, large display screens for calculators, electronic math worksheets, videotaped math lessons, computer-assisted instruction, etc. Students with specific needs can use specialized software with built-in tools to enhance receptive and expressive language learning. For example, students with sensory challenges can use numerous technologies, such as electronic braille, electronic viewers, PECS symbols, Math Braille Talk, and videos. Tools like vibrating pencils, software for the hearing-impaired, apps for dyslexia, and specialized keyboards can assist various students with distinct learning disabilities (Jon, 2016).

\subsection{Multi-Media Technology}

Laptops working in conjunction with electronic whiteboards and/or projectors can improve the learning process of students with special needs. Using technology in learning can enable teachers to access every student's learning style by utilizing a platform that can be used to accomplish the students' work at their own pace. In addition, teachers can integrate learning with various activities, project-based learning, one-on-one coaching, and peer support, which makes learning more interactive and fun. Wise utilization of technology in the classroom can allow teachers to tailor learning to a student's individual needs, which provides distinct benefits and helps to model the learning process to different cognitive and sensory weaknesses (Fearon, Starr, \& McLaughlin, 2011; Fernández-López, Rodríguez-Fórtiz, Rodríguez-Almendros, \& Martínez-Segura, 2013; Bausch, \& Hasselbring, 2004). Bausch and Hasselbring (2004) reported that the use of technology in the classroom would increase students' interest and help them enjoy learning. Besides, using the latest software programs and multimedia devices designed for special-needs students increases the success of their inclusion in regular classrooms.

Other multimedia educational tools have been created with the support of ICT to help children with SENs to receive proper education (Cantón, González, Mariscal, \& Ruiz, 2007). For example, SENs teachers may encounter problems using a computer or iPad. These tools have a rapid entry into schools with high expectations. Multimedia devices such as laptops, interactive whiteboards, projectors, microphones, and recording devices are expected to improve student learning, raise the productivity of teachers, and make children work within an information-based society. Cantón et al. (2007) reported that SENs teaching could improve with better curriculum adaptation to student needs and better use of accessible multimedia tools. Thus, they developed a framework based on their educational resource (Proyecto Aprende), which provides internet help for students with special needs. Their framework supports teachers and multimedia educational tool developers working with SENs students and, most importantly, the students themselves (Canton et al., 2007, p. 6).

\subsection{The Picaa Platform - A Platform for Customized Learning Activities}

Picca can be used in classrooms to help students with SENs develop and improve their learning skills, such as language, math, autonomy, and social interaction (Fernández-López et al., 2013). This platform is a mobile platform based on an iPad and iPod touch device. It was designed to cover the main phases of learning operations, such as preparation, use, and evaluation. It is considered an excellent tool that supports SENs adaptation. The use of ICT has played a central role in shaping knowledge and skills for both learners and teachers (Drigas \& Ioannidou, 2013). Various studies on the ICT effect can be found in the presentations of Mohammed and Almekhlafi (2017) and Morrison (2007), who introduced different technologies that help students with SENs learning.

Technology has invaded every aspect of our lives. We use it every day at home, school, and in public life. Several new technologies incorporate the global positioning system (GPS), which can be incorporated into many activities like field testing, surveying, traveling to unknown locations, and getting to meetings on time. ICT's role in the teaching and learning process is constantly increasing, pressuring teachers to prove that they are capable of using technology to boost their potential (Zhao, 2003). Many technologies are considered an essential part of teachers' professional qualifications (CEO Forum on Education and Technology, 1999). However, 
difficulties may prevent the efficient implementation of technology into the classroom for learning and teaching purposes. These difficulties include access, time, resources, training, attitudinal effects, beliefs, practices, institutional and administrative support, experience, and resistance to technology integration (Earle, 2002; Gulbahar \& Guven, 2008). Overcoming these difficulties will take time, effort, and powerful political intervention, which includes the removal of some negative philosophical and pedagogical assumptions in the educational system. Vrasidas and McIsaac (2010) emphasized that teachers are the cornerstone for any change in the educational system. Therefore, reforming teacher education programs by ensuring they have the training and qualifications needed to use various technologies is the best place to start. Negative knowledge and beliefs about technology among teachers can be changed when technology is perfectly integrated into their classroom (Criswell, 1989; Handler, 1992).

\subsection{The Role of Technology in SENs Education}

The role of technology in SENs education is even more important than its role in general education because it facilitates the complexity of the material and addresses the individual needs of the learners. Similarly, integrating technologies into the classroom can create learning activities and establish an inclusive learning environment dedicated to children with disabilities to learn and play with each other (Bess, Dodd-Murphy, \& Parker, 1998). This type of integration can provide SENs students with various influences that can improve motivation and generate positive attitudes, achievements, social and cultural experiences, as well as peer interactions in classrooms (Guzman \& Schofield, 1995). However, it has been established that many graduates of teacher education programs do not feel adequately skilled in integrating the technology needed to support students with special needs (Gronseth et al., 2010; Dinçer, 2018). Consequently, pre-service teachers must be involved in a training program with a supportive environment that enables them to be prepared for their first year of teaching and for the different challenges that lie ahead. According to Dinçer (2018), "Knowledge, skills, and attitudes of future teachers should be paired with each other and handled together to ensure this integration and, thus, teacher training should give full play to technology literacy and technology teaching” (p. 2703). If the pre-service teachers are not well-prepared, they will face some barriers in using technology in their classrooms, as reported by Hasselbring and Glaser (2000). They affirmed that the lack of appropriate technology training in pre-service and in-service teacher education programs is the most cited barrier to using technology in education, which negatively affects the achievement of goals in educational programs for students with disabilities. Handler and Pigott (1995) stated that pre-service teachers reported they were prepared to integrate computer technology in class, yet they did not have the opportunity to extend their experience through the teacher preparation program set apart for ICT technology training. Also, Mohamed's (2018) study posits that teachers have a positive attitude toward engaging technology in teaching, but they need more training in using computer technology in class and a more systematic plan to integrate this use effectively.

The Koc and Bakir (2010) study agrees that pre-service teachers are prepared to integrate computer technology in class but need more training to master this knowledge. This result shows expressed feelings of discomfort, distress, and concern about using technology (Stone, 1998). Once teachers master the use of technology by proper training, they will be able to:

create relationships between active learning and active teaching, develop an appreciation and an understanding of the potential of technology, learn to be authors of multimedia software, develop leadership skills, become role models for successful integration, understand the power of technology integration, design integrated curriculum activities, learn the benefits of technology in the classroom, develop ownership of the technology through authentic experiences, learn to motivate students with technology, achieve success by becoming informed and reflective decision-makers, and become advocates for technology integration (Shelley as mentioned in Wright \& Macrow, 2006, p. 2).

Sabzian and Gilakjani (2013) recommended that the training of teachers should not only include how they can use computer technology but also how they can make use of computer technology to improve the quality and effectiveness of their teaching. They also recommended that this training include how technology can be effectively integrated into the curriculum.

\section{Methodology}

\subsection{Ethical Considerations}

Participation in this study was voluntary. The participants were provided with a consent letter that explained the aim of this study. It clearly stated that their responses would be reported anonymously, which meant that their identity would, in no way, be attached to the answers provided. 


\subsection{Design and Participants}

In this study, a quantitative-oriented "needs assessment" method was used to define the background information and needs of pre-service special education teachers in educational technology use and probable gaps in teachers' preparation programs linked to integrating technology in teaching. Because Saudi Arabia segregates educational institutions by gender, a sample of female pre-service special education graduate students was selected to participate in a pencil-and-paper survey regarding their perceptions toward their preparation to integrate computer technology in teaching and their level of comfort in using technology applications. The survey was given at a public university to the six female faculty members who were teaching a total of 83 students in four paths of a special education department (learning disabilities, intellectual disability, hearing loss from deaf to hard of hearing, and autism). After three weeks, data collection ceased and 58 surveys had been completed. The demographic summary of the participants is described in Table 1.

Table 1. Demographic description of the sample

\begin{tabular}{cccc}
\hline Variables & & Frequency & Percentage \\
\hline \multirow{3}{*}{ Age } & Less than 21 years & 1 & 1.7 \\
& $21-25$ & 52 & 89.9 \\
& $26-30$ & 5 & 8.6 \\
Special education paths & Learning disabilities & 16 & 27.6 \\
& Intellectual disabilities & 7 & 12.1 \\
& Deaf disabilities & 15 & 25.9 \\
\multirow{2}{*}{ Experience using computers } & Autism & 20 & 34.5 \\
& $1-4$ years & 7 & 12.1 \\
& 5-8 years & 12 & 20.7 \\
Training on computer technology & More than 8 years & 39 & 67.2 \\
& Received training & 16 & 27.7 \\
& Did not receive training & 42 & 72.4 \\
\hline
\end{tabular}

\subsection{Instrument}

The survey was adopted from an instrument created by previous researchers (Koc \& Bakir, 2010) after obtaining their permission and was translated into Arabic by the authors. Afterwards, it was translated back to English by export in translation. Parallel forms reliability was used in the development of the survey. This measurement was obtained using two different versions of the survey. These versions covered the same concepts, knowledge, skills, etc. and were administered to the same population (Phelan \& Wren, 2006). The validity of the instrument was then improved by consulting ten experts in three fields (English language, educational technology, and special education) who provided their evaluations.

A pilot study to measure the reliability was conducted with 15 pre-service teachers at one institution. The reliability coefficient (Cronbach's alpha) from the results was 0.890 , which suggested that the survey instrument was stable enough to determine participants' preparation to integrate computer technology in teaching and their level of comfort in using technology applications.

The final instrument consisted of four sections: (a) demographic information (age, course path in special education, prior experience with information technology that included years of experience in using computers, and whether the survey participant had received training in using computer technology); (b) 11 statements were obtained regarding perceptions about participants' knowledge and preparation in various aspects of using technology for course planning, teaching, assessment, and communication, which required responses using a five-point Likert scale, ranging from strongly disagree to strongly agree, (c) open-ended question about the barriers of integrating computer technology in teaching from the pre-service teachers' perspective, and (d) statements regarding 10 computer technological applications and their level of relevance according to the participant's path (using a three-point Likert scale of low, medium, and high).

\subsection{Data Collection}

The data were collected through pencil-paper surveys. To make sure that all special education pre-service teachers received the survey, the researchers gave each faculty member the exact number of surveys that matched the number of students they had in class. The participants were asked to volunteer to complete the survey on needs assessment, and a consent form was included. After three weeks, the faculty members returned 
the exact number of surveys that had been handed to them. Incomplete surveys were excluded. A total of 58 pre-service special education teachers participated out of 83 , which formed $69.88 \%$ of the response rate.

\subsection{Data Analysis}

The statistical software SPSS processed the data for quantitative analysis. Descriptive statistics such as frequency and percentage as well as mean and standard deviation were calculated to understand pre-service special education teachers' perceptions of their preparation for integrating computer technology in education. These measurements were also used to determine the level of relevance of technology applications according to each participant's path in their special education program. The open-ended questions were coded to identify key patterns and themes that emerged from the responses.

\section{Results and Discussion}

\subsection{Experience in Using Computers}

One purpose of this study was to discover pre-service special education teachers' prior experience in using computers. Frequency and percentage were used to analyze the data. As shown in Table 2, most participants $(67.2 \%, \mathrm{n}=39)$ had used computers for more than eight years. Also, most participants $(72.4 \%, \mathrm{n}=42)$ had not received training courses in the usage of computers. This response shows that the participants obtained their computer skills in a manner that aligned with Koc and Bakir's (2010) study.

Table 2. Frequency and percentage of participants' prior experience

\begin{tabular}{cccc}
\hline Variable & & Frequency & Percent (\%) \\
\hline & Less than 4 years & 7 & 12.1 \\
Experience in using computer technology & From 5-8 years & 12 & 20.7 \\
& More than 8 years & 39 & 67.2 \\
\multirow{2}{*}{ Received training courses in the use of computer technology } & Yes & 16 & 27.6 \\
& No & 42 & 72.4 \\
\hline
\end{tabular}

\subsection{Knowledge and Preparation of Computer Technology Integration in Teaching}

Another purpose of the research was to discover the pre-service special education teachers' perception of the knowledge and preparation needed to integrate computer technology in teaching. The mean and standard deviation responses were used to analyze the data. The results show that most of the participants were generally prepared to integrate computer technology in teaching $(77 \%, \mathrm{n}=45)$. Table 3 shows the mean and standard deviation responses of participants to each statement. This result aligned with prior studies (Koc \& Bakir, 2010; Handler \& Pigott, 1995) that found that teachers and pre-service teachers stated that they were well prepared to integrate computer technology in teaching. 
Table 3. Participants' perceptions of integrating computer technology

\begin{tabular}{|c|c|c|}
\hline Statement & Mean & $\begin{array}{l}\text { Standard } \\
\text { Deviation }\end{array}$ \\
\hline I am comfortable with planning lessons and curriculums that involve student use of technology during instruction. & 4.22 & 0.68 \\
\hline I am prepared to use technology to regularly communicate and collaborate with peers in the field of education. & 4.12 & 0.82 \\
\hline $\begin{array}{l}\text { I need training to learn how to integrate computer technologies into my instruction in order to enhance student } \\
\text { learning. }\end{array}$ & 4.09 & 0.75 \\
\hline $\begin{array}{l}\text { The college/university prepared me so that I consider the computer as an integral component for all aspects of teaching } \\
\text { and learning. }\end{array}$ & 4.09 & 0.81 \\
\hline I can use computers as drill-practice and tutorial tools in my instruction. & 3.93 & 1.01 \\
\hline I find technology frustrating to use when I do not receive adequate support. & 3.90 & 0.91 \\
\hline I can use computers to engage students in critical and higher-order thinking. & 3.88 & 0.90 \\
\hline I am well prepared for using technology as a teaching tool. & 3.86 & 0.96 \\
\hline $\begin{array}{l}\text { In my education courses, I received enough information about the effective use of technology as a learning tool for } \\
\text { students. }\end{array}$ & 3.84 & 0.85 \\
\hline I have strategies for using computer technology to individualize instruction and meet the needs of diverse learners. & 3.81 & 0.87 \\
\hline $\begin{array}{l}\text { As appropriate to my field, I am prepared to consider the social, ethical, and legal implications of using computer } \\
\text { technology in my lessons. }\end{array}$ & 3.71 & 0.92 \\
\hline I have strategies for using computer technology to manage student assessment. & 3.71 & 0.94 \\
\hline $\begin{array}{l}\text { When planning how to use computer technologies in teaching, I based my selections on current research regarding the } \\
\text { effectiveness of those technologies. }\end{array}$ & 3.50 & 0.96 \\
\hline I am familiar with national and international technology standards in teaching my students. & 3.19 & 1.03 \\
\hline Overall & 3.85 & 0.53 \\
\hline
\end{tabular}

As shown in Table 3, pre-service special education teachers agreed with most of the statements within acceptable mean and standard deviation results $(\mathrm{M}=4.22, \mathrm{SD}=0.68$ and $\mathrm{M}=3.50, \mathrm{SD}=0.96)$. On the other hand, their response to the statement "I am familiar with national and international technology standards in teaching" was neutral $(\mathrm{M}=3.19, \mathrm{SD}=1.03)$, which means that the participants either did not understand the statement or did not have any knowledge about national and international technology standards in teaching. The result of the preparation aligns with the findings of Koc and Bakir (2010) and Hasselbring and Glaser (2000), but not with Alkahtani (2013), who conducted a survey where most of the participants reported they were poorly prepared (75.6\%, $\mathrm{n}=96)$. The Alkahtani (2013) survey was on assistive technology only, and the participants were female and male teachers from different levels of education, while the recent research focus was on pre-service special education teachers in one college of education and their perception about using computer technology.

\subsubsection{More Practice Through Training}

Although the results revealed that pre-service special education teachers were prepared to integrate computer technology into education, Alkahtani (2013) also reported teachers response to "I need training to learn how to implement computer technologies into my instruction in order to enhance student learning" a mean of 4.09 with a standard deviation of 0.75 , which means teachers strongly agree to this statment. This result aligns with the Koc and Bakir (2010) study and the Hasselbring and Glaser (2000) study.

Responding to the open-ended question about their perceptions of their preparation to integrate technology in teaching, a pre-service special education teacher said: "The number of courses from Educational Technology Department, which is required in our special education program, is not enough for us to be ready to apply computer technologies in teaching." Likewise, a special education pre-service teachers declared, "I know the importance of using technology in teaching, especially with special needs children; thus, I need more training to master some programs and software." On the other hand, a pre-service special education teacher mentioned the different skills she and her peers gained by writing: "My friend learned how to use PowerPoint in teaching with a different instructor, while I learned how to integrate the scientific journey with another instructor in the same semester." The differences in student responses about the kind of computer technology they learned to integrate into teaching were explained by one of the researchers, an instructor in a university's educational technology department. She saw the various outcomes of the program due to the number of instructors who taught the same course on integrating technology into the learning environment. This course is a requirement in the study plan of all the departments in the college of education. Instructors had the option of choosing any computer technology program or software to teach special education pre-service teachers how to integrate them into teaching. Multiple 
choices would naturally yield multiple responses from students who took those courses.

\subsection{Barriers to Integrating Computer Technology in Teaching}

The third purpose of this study is to identify the barriers to integrating computer technology in teaching according to the pre-service special education teachers' perspective. The coding, grouping, organizing, and themes were used to analyze the data. The results indicated several barriers to using computer technology in teaching students with disabilities. These barriers have been divided into the following categories: lack of equipment, lack of knowledge and training, maintenance, and technical problems. These findings align with Hasselbring and Glaser's (2000) report on the high cost of equipment, which significantly obstructs the use of technology in the classroom. Additionally, the findings were supported by Koc and Bakir's (2010) results where $38.5 \%$ of the participants reported "lack of knowledge," $31 \%$ reported "lack of equipment," $8 \%$ reported "maintenance problems," and $8 \%$ reported "internet connection" as barriers to using technology in teaching. Riasati et al. (2012, pp. 27-28) provided the following suggestions on how to address these barriers:

Teacher training centers should work towards providing teachers with sufficient computers, Internet access, and technical support. Additionally, as time is a legitimate concern of teachers to plan technology-based lessons, to surf the different websites, and to cover sufficient content in the allotted time frames, schools should provide teachers with sufficient time to spend on incorporating technology into their teaching practice. For example, giving opportunities to teachers during regular professional development courses to explore different aspects of technology can help them increase their confidence in using technology and thereby change their negative attitude, "lack of time" and "lack of effective training.

The first barrier that pre-service special education teachers reported regarding integrating computer technology in special education classrooms was the lack of equipment and software programs. Most of the participants stated this obstacle in the open-ended questions. The participants were engaged in pre-service instruction in different urban schools. One pre-service special education teacher wrote, "I used PowerPoint software to design one of my lessons so autistic students can go through the material by themselves, but the class didn't have enough devices for each student." Another survey participant mentioned that "lack of devices make it hard on us, plus some devices do not work." A pre-service special education teacher stated, "Allowing two or more students to share a device doesn't help them learn due to their special needs. Although there is enough devices in the class but some of them doesn't work." Moreover, a pre-service special education teacher wrote, "lack of devices and out-of-date ones waste my effort and time in design and production, and finally results in not using the program or material". Researchers blame this obstacle on the low budget allocated by the Ministry of Education for special education, which caused a shortage of computer devices and software programs required to meet the needs of students with disabilities. The lack of maintenance services also led to the abandonment of all the computers due to the variance between the number of students and the number of working devices during hands-on class activities.

The second barrier that pre-service special education teachers reported was a lack of knowledge and training on using some computer technologies. One participant wrote, "What I learned is enough and I need more practice (hands-on) to master some of the computer technologies." One pre-service teacher explained the need for training as follows: "As I'm a beginner in using computer technology, I wish there was a training course that goes step-by-step from designing to implementing the technology in teaching." Another participant added that "more courses in integrating education technology will help me feel more confident to use it with special needs students of any age," and a pre-service special education teacher stated that "I need to learn about software and programs that can suit autism students." These statements suggest how much pre-service special education teachers need knowledge and training courses or programs that could help them build their confidence in using computer technology in teaching students with special needs. This reflects on the findings of the this study that participants reported knowledge and experience in using computer technology but not in using technology in educational settings.

For the pre-service special education teachers who participated in this study, addressing technical (maintenance) problems was one of the barriers to integrating computer technology in teaching. These problems include slow internet connection, unreliable internet provider, and unresponsive IT support. A participant wrote that "the school where I am receiving my training doesn't have an internet connection," while another pre-service teacher stated that, "I can't use YouTube due to the slow internet speed." These barriers can lead to frustration and abandonment of the technology because of technical difficulties and highlight the need for proper coordination of information technology (IT) support for classroom use. It also underlines the importance of collaboration 
among all personnel involved in integrating technology in education. For example, the integration of technology will be more successful when supported by school administrators, IT personnel, and the governing administration, as well as the classroom teacher.

\subsection{Pre-Service Teachers' Level of Confidence Gained from Using Technology Applications in Teaching}

\subsubsection{Pre-Service Teachers' Level of Comfort with ICT Devices}

Another barrier raised by pre-service special education teachers in integrating computer technology in the classroom was the fear of students misusing the electronic devices (e.g., computers, iPads, mobile phones). One participant mentioned that, "Students with special needs must be observed while using a device because they may break it," while another wrote, "Autistic students may throw the device if they feel scared." These statements reflect a lack of knowledge among the survey participants about best practices in introducing computer technology to students with special needs. They also suggest that the technology courses the teachers studied were focused more on theory rather than practical applications. The participants themselves commented that they needed more practice in using technology in their classrooms. They also stressed the importance of introducing computer technology to children with special needs before the age of three so that they may obtain the necessary skills in using computer technology in alignment with school goals. These necessary skills include operating a computer and navigating the internet (Tinio, 2002; Wartella, Schomburg, Lauricella, Robb \& Flynn 2010).

\subsubsection{Pre-Service Teachers' Level of Comfort Using Technology Applications}

The ultimate purpose of this study was to determine pre-service special education teachers' level of comfort in using technology applications. The frequency, percentage, mean, and standard deviations of each application in this section were used. Table 4 displays the mean scores of participants' ratings of the applications in descending order. Ten applications were rated on a three-point scale.

Table 4. Comfort level with technology applications

\begin{tabular}{|c|c|c|c|c|c|c|c|c|}
\hline \multicolumn{3}{|c|}{ Computer's Applications } & \multirow{3}{*}{$\begin{array}{c}\text { Low } \\
0 \\
0\end{array}$} & \multirow{3}{*}{$\begin{array}{c}\text { Mid } \\
8 \\
13.8\end{array}$} & \multirow{3}{*}{$\begin{array}{c}\text { High } \\
51 \\
87.9\end{array}$} & \multirow{3}{*}{$\frac{\text { Mean }}{2.88}$} & \multirow{3}{*}{$\begin{array}{l}\text { SD } \\
0.35\end{array}$} & \multirow{3}{*}{$\begin{array}{c}\text { Ranking } \\
1\end{array}$} \\
\hline & & $\mathrm{N}$ & & & & & & \\
\hline 1) & Presentation software (e.g., PowerPoint) & $\%$ & & & & & & \\
\hline \multirow{2}{*}{ 2) } & \multirow{2}{*}{ Search engines } & $\mathrm{N}$ & 3 & 7 & 48 & \multirow{2}{*}{2.79} & \multirow{2}{*}{0.53} & \multirow{2}{*}{2} \\
\hline & & $\%$ & 5.17 & 12.07 & 82.76 & & & \\
\hline \multirow{2}{*}{ 3) } & \multirow{2}{*}{ Internet communication applications (e.g., email, forums, chat) } & $\mathrm{N}$ & 3 & 8 & 47 & \multirow{2}{*}{2.77} & \multirow{2}{*}{0.54} & \multirow{2}{*}{3} \\
\hline & & $\%$ & 5.17 & 13.8 & 81.03 & & & \\
\hline \multirow{2}{*}{ 4) } & \multirow{2}{*}{ Word processors } & $\mathrm{N}$ & 2 & 12 & 44 & \multirow{2}{*}{2.74} & \multirow{2}{*}{0.52} & \multirow{2}{*}{4} \\
\hline & & $\%$ & 3.44 & 20.7 & 75.86 & & & \\
\hline \multirow{2}{*}{ 5) } & \multirow{2}{*}{ Hypermedia/Hypertext applications } & $\mathrm{N}$ & 9 & 7 & 42 & \multirow{2}{*}{2.60} & \multirow{2}{*}{0.73} & \multirow{2}{*}{5} \\
\hline & & $\%$ & 15.51 & 12.08 & 72.41 & & & \\
\hline \multirow{2}{*}{ 6) } & \multirow{2}{*}{ Drill-practice programs, tutorials } & $\mathrm{N}$ & 3 & 22 & 33 & \multirow{2}{*}{2.55} & \multirow{2}{*}{0.57} & \multirow{2}{*}{6} \\
\hline & & $\%$ & 5.17 & 37.93 & 56.9 & & & \\
\hline \multirow{2}{*}{ 7) } & \multirow{2}{*}{ Concept mapping applications (e.g. Inspiration) } & $\mathrm{N}$ & 12 & 22 & 24 & 223 & 076 & 7 \\
\hline & & $\%$ & 20.7 & 37.93 & 41.37 & 2.23 & 0.10 & 1 \\
\hline 8) & Video editing software (e $\sigma$ Adohe Premiere iMevie) & $\mathrm{N}$ & 14 & 28 & 16 & 205 & 072 & 8 \\
\hline 8) & Video editıng soltware (e.g., Adobe Premiere, 1Movie) & $\%$ & 24.13 & 48.27 & 27.6 & 2.05 & 0.12 & 8 \\
\hline 9) & Webpage designing applications (e.g. HTML, FrontPage, Composer) & $\mathrm{N}$ & 27 & 19 & 12 & 176 & 079 & 9 \\
\hline & & $\%$ & 46.55 & 32.75 & 20.7 & 1.16 & 0.19 & 9 \\
\hline 10) & Datahases (e $g$ Access) & $\mathrm{N}$ & 35 & 15 & 8 & 155 & 074 & 10 \\
\hline & Databases (e.g., Access) & $\%$ & 60.34 & 25.86 & 13.8 & 1.55 & 0.74 & 10 \\
\hline
\end{tabular}

These results did not align with the study of Koc and Bakir (2010), where participants reported their high level of comfort with word processors $(\mathrm{M}=2.92, \mathrm{SD}=0.27)$, while video editing software $(\mathrm{M}=1.23, \mathrm{SD}=0.52)$ was the most difficult to work with. According to the same study, teachers are most comfortable with presentation programs (PowerPoint) and search engines (e.g., Google), while instructional programs, such as drill and practice tutorials and video editing software, were the least comfortable programs to use. 


\section{Recommendations and Conclusions}

This research contributes to the discussion about preparing pre-service special education teachers to use technology effectively in their practice and the effectiveness of preparation programs designed to train them adequately. The findings of this research reveal that pre-service special education teachers have skills and knowledge in computer applications but lack the knowledge to integrate these technologies into their teaching practices. Also, respondents were eager to acquire more knowledge and training in integrating new computer software and devices to help them gain enough confidence in using them in teaching. Based on the results of the survey, the researchers recommend the following:

1) Intensify or enhance the technology courses in programs that prepare special education teachers and focus on the practical aspects of integrating technology in teaching.

2) Provide the necessary support to increase the efficiency of the use of computers in the education of students with disabilities, such as periodic maintenance of the devices in schools, consistent internet connection, and the availability of technical support.

3) Provide an adequate number of computers in special education classes.

4) Provide the latest computer hardware and software for students with disabilities.

5) Provide training courses for teachers who are not trained in the use of computers to improve their efficiency and to promote their use in the educational process.

6) Enhance cooperation between specialists in the field of special education and the field of technology to create educational programs suited to the needs of students with disabilities.

7) Provide information about the needs of special education teachers that can be used to build partnerships with schools and universities around the world who have special qualitative professional development programs that the Ministry of Education can adopt to support the development of our teachers.

\section{References}

Abercrombie, J. L. (2016). Improving students' performance in elementary math using iPad technology: An action research study (ProQuest Number: 10151230) (Doctoral dissertation, Capella University). ProQuest.

Al sheha, S. A. (2005). Derasa taqwemeyah lestekdam altekneyat altaleymeyah fe Mahad Alamal lelsum fe Riyadh [Evaluation study for the use of educational technology in Alamal institutes for deaf in Riyadh] (Master dissertation, King Saud University). King Fahad National Library.

Al-johanin, S. A., \& Al-zarea, N. A. (2014). Obstacles of using educational methods in teaching reading by teachers of learning disabilities students. International Interdisciplinary Journal of Education, 3(10). Retrieved from www.doi.org/10.12816/0007273

Alkahtani, K. D. (2013). Teachers' knowledge and use of assistive technology for students with special educational needs. Journal of Studies in Education, 3(2). https://doi.org/10.5296/jse.v3i2.3424

Anderson, S. E., \& Putman, R. S. (2020). Special Education Teachers' Experience, Confidence, Beliefs, and Knowledge About Integrating Technology. Journal of Special Education Technology, 35(1), 37-50. https://doi.org/10.1177/0162643419836409

Andretta, S. (2006). Information literacy: challenges of implementation. ITALICS Innovations in Teaching and Learning in Information and Computer Sciences, 5(1), 1-6. https://doi.org/10.11120/ital.2006.05010001

Banister, S., \& Ross, C. (2005). From High School to College: How Prepared Are Teacher Candidates for Technology Integration? Journal of Computing in Teacher Education, 22(2), 75-80. https://www.doi.org/10.1080/10402454.2005.10784540

Bates, A. W., Bates, T., \& Sangra, A. (2011). Managing technology in higher education: Strategies for transforming teaching and learning. John Wiley \& Sons.

Bausch, M. E., \& Hasselbring, T. S. (2004). Assistive technology: Are the necessary skills and knowledge being developed at the preservice and in-service levels? Teacher Education and Special Education, 27(2), 97-104. https://doi.org/10.1177/088840640402700202

Bess, F. H., Dodd-Murphy, J., \& Parker, R. A. (1998). Children with minimal sensorineural hearing loss: prevalence, educational performance, and functional status. Ear and Hearing, 19(5), 339-354. https://doi.org/10.1097/00003446-199810000-00001

Cantón, P., González, A. L., Mariscal, G., \& Ruiz, C. (2007). Towards a Methodology for Educating Students 
with Special Needs. In 5th Conference and Workshop on Assistive Technology for People with Vision and Hearing Impairments, CVHI. Citeseer. Retrieved from http://ceur-ws.org/Vol-415/paper6.pdf

CEO Forum on Education and Technology. (1999). Professional development: A link to better learning. The CEO Forum school technology and readiness report-year two. Washington, DC: Author.

Criswell, J. R. (1989). Rethinking microcomputer instruction as a part of teacher education reform. Educational Technology, 29(11), 40-43. Retrieved from https://www.jstor.org/stable/44426043

Dinçer, S. (2018). Are preservice teachers really literate enough to integrate technology in their classroom practice? Determining the technology literacy level of preservice teachers. Education and Information Technologies, 23(6), 2699-2718. https://doi.org/10.1007/s10639-018-9737-z

Drigas, A., \& Ioannidou, R. E. (2013). Special education and ICTs. International Journal of Emerging Technologies in Learning (iJET), 8(2), 41-47. https://doi.org/10.3991/ijet.v8i2.2514

Earle, R. S. (2002). The integration of instructional technology into public education: Promises and challenges. ET Magazine, 42(1), 5-13. $\quad$ Retrieved from https://www.jstor.org/stable/44428716?seq=1\#metadata_info_tab_contents

Edyburn, D. L. (2000). Assistive technology and students with mild disabilities. Focus on Exceptional Children, 32(9), 1-24. https://doi.org/10.17161/fec.v32i9.6776

Elsersy, A. M., Ibrahim, M. D., \& Esayed-Sedeg, M. (2016). Estekdam alcomputer (Alhaseb Alali) dakel bea almoeakeen sumeyan [The use of computer within the environment of hearing impaired students]. Educational Sciences, $4(3)$. $\quad$ Retrieved from http://search.shamaa.org/PDF/Articles/EGJes/JesVol24No4P3Y2016/jes_2016-v24-n4-p3_403-422.pdf

Fearon, C., Starr, S., \& McLaughlin, H. (2011). Value of blended learning in university and the workplace: Some experience of university students. Industrial and Commercial Training, 43(7), 446-450. https://doi.org/10.1108/00197851111171872

Fernández-López, Á., Rodríguez-Fórtiz, M. J., Rodríguez-Almendros, L. M., \& Martínez-Segura, M. J. (2013). Mobile learning technology based on iOS devices to support students with special education needs. Computers and Technology, 61, 77-90. https://doi.org/10.1016/j.compedu.2012.09.014

Frigaard, A. (2002). Does the Computer Lab Improve Student Performance on Vocabulary, Grammar, and Listening Comprehension? (Master's thesis, University of Wisconsin). ERIC. Retrieved from http://eric.ed.gov/PDFS/ED476749.pdf

General Authority for Statistics. (2018). GaStat: (2.9\%) of Saudi population have disability with (extreme) difficulty. Retrieved from https://www.stats.gov.sa/ar/news/230\#.Xdv0EuLw6AY

Girgin, Ü., Kurt, A. A., \& Odabaşı, F. (2011). Technology integration issues in a special education school in Turkey. Cypriot Journal of Educational Sciences, 6, 13-21. Retrieved from https://www.academia.edu/35529109/Technology_integration_issues_in_a_special_education_school_in_T urkey

Gronseth, S., Brush, T., Ottenbreit-Leftwich, A., Strycker, J., Abaci, S., Easterling, W., ... \& van Leusen, P. (2010). Equipping the next generation of teachers: Technology preparation and practice. Journal of Digital Learning in Teacher Education, 27, 30-36. https://doi.org/10.1080/21532974.2010.10784654

Gulbahar, Y., \& Guven, I. (2008). A survey on ICT usage and the perceptions of social studies teachers in Turkey. Journal of Educational Technology \& Society, 11(3), 37-51.

Guzman, N., \& Schofield, R. (1995). Systemic restructuring for successful inclusive schools: Leadership and collaborative evaluation model. Paper presented at the Annual Meeting of the American Association of School Administrators (AASA) (ERIC Document ED 380 863). February 10-13, New Orleans, LA.

Handler, M. (1992). Successful strategies for increasing technology in preservice programs, in Technology and Teacher Education Annual, MCE, Charlottesville, Virginia, USA (pp. 326-328).

Handler, M. G., \& Pigott, T (1995). Technology preparation for preservice teachers: do they feel prepared for 21 st century classrooms? In J. D. Tinsley et al. (Eds.), World Conference on Computers in Education VI. https://doi.org/10.1007/978-0-387-34844-5_97

Hasselbring, T. S., \& Glaser, C. H. W. (2000). Use of computer technology to help students with special needs. The Future of Children, 10(2), 102-122. https://doi.org/10.2307/1602691 
Hawsawi, A. M. (2002). Teachers Perceptions of Computer Technology Competencies working with students with mild Cognitive Delay (Doctoral dissertation). University of Idaho, USA.

Hawsawi, A. M. (2007, July). Moawegat estekdam altekneyat altaleymeyah alkasah fe tadres atalameth almotakalefen aqleyan kama yodrekoha moalemo atarbeya alfekreyah fe Riyadh [Obstacles of using of special educational techniques in teaching mentally students as perceived by Intellectual Education teachers in Riyadh]. Paper presented at the First scientific conference of the Department of Mental Health "Special Education between reality and hope". Benha University, Egypt. Retrieved from http://dr-banderalotaibi.com/new/admin/uploads/3/15f.pdf

Jon. (April, 2016). 5 Digital Tools for Students with Special Needs. Retrieved from http://webcache.googleusercontent.com/search?q=cache:Wn0vFBGUIEQJ:www.livetiles.nyc/5-digital-tools -students-special-needs $/+\& \mathrm{~cd}=1 \& \mathrm{hl}=\mathrm{en} \& \mathrm{ct}=\mathrm{clnk} \& \mathrm{gl}=\mathrm{sa}$

Kärnä-Lina, E., Pihlainen-Bednarika, K. Sutinenb, E., \& Virnesb, M. (2007). Technology in Finnish Special Education-Toward Inclusion and Harmonized School Days. Informatics in education, 6(1), 103-114. https://doi.org/10.15388/infedu.2007.07

Koc, M., \& Bakir, N. (2010). A needs assessment survey to investigate pre-service teachers' knowledge, experiences, and perceptions about preparation to using educational technologies. Turkish Online Journal of Educational Technology-TOJET, 9(1), 13-22. Retrieved from http://www.csa.com

Lam, Y., \& Lawrence, G. (2010). Teacher-Student Role Redefinition During a Computer-Based Second Language Project: Are Computers Catalysts for Empowering Change? Journal Computer Assisted Language Learning, 15(3), 295-315. https://doi.org/10.1076/call.15.3.295.8185

Mohamed, A. H. H. (2018). Attitudes of special education teachers towards using technology in inclusive classrooms: A mixed-methods study .Journal of Research in Special Educational Needs, 18(4), 278-288. https://doi.org/10.1111/1471-3802.12411

Mohammed, A. H. H., \& Almekhlafi, A. G. (2017). English Language Teachers' Perceptions of Using ICT in Teaching in Cycle Three in the United Arab Emirates. US-China Foreign Language, 15(6), 349-366. Retrieved from https://pdfs.semanticscholar.org/de19/d8c09f94123f92e344ff15bee96356b9494f.pdf

Morrison, K. (2007). Implementation of Assistive Computer Technology: A Model for School Systems. International Journal of Special Education, 22(1), 83-95.

Mwalongo, A. (2011). Teachers' perceptions about ICT for teaching, professional development, administration, and personal use. International Journal of Education and development using information and communication Technology, 7(3), 36.

National Research Council. (2000). How People Learn: Brain, Mind, Experience, and School: Expanded Edition. Washington, DC: The National Academies Press.

Oliver, A., Osa, J. O., \& Walker, T. M. (2012). Using instructional technologies to enhance teaching and learning for the 21 st century prek-12 students: The case of a professional education programs unit. International Journal of Instructional Media, 39(4), 283-296.

Phelan, C., \& Wren, J. (2006). Exploring reliability in academic assessment. Retrieved from https://www.uni.edu/chfasoa/reliabilityandvalidity.htm

Posada, M., Primo, P. G., Ferrari, M. J., \& Martín-Arribas, M. C. (2007). European Autism Information System (EAIS) Report on the 'Autism Spectrum Disorders Prevalence Data and Accessibility to Services' Questionnaire (Q-EAIS). Madrid, Spain: Research Institute for Rare Diseases, Instituto de Salud Carlos III. Retrieved from http://ec.europa.eu/health/archive/ph_information/dissemination/diseases/docs/autism1.pdf

RAND Europe. (2013). Support for children with special educational needs (SEN). Brussels, Belgium: European Commission.

Riasati, M. J., Allahyar, N., \& Tan, K-E. (2012). Technology in language education: Benefits and barriers. Journal of Education and Practice, 3(5), 25-30.

Richtel, M. (2010). Growing up digital, wired for distraction. The New York Times, 21, 1-11.

Sabzian, F., \& Gilakjani, A. P. (2013). Teachers' attitudes about computer technology training, professional development, integration, experience, anxiety, and literacy in English language teaching and learning. International Journal of Applied Science and Technology, 3(1), 67-75. Retrieved from http://ijastnet.com/journals/Vol_3_No_1_January_2013/9.pdf 
Sabzian, F., Gilakjani, A. P., \& Sodouri, S. (2013). Use of Technology in Classroom for Professional Development. Journal of Language Teaching \& Research, 4(4). https://doi.org/10.4304/j1tr.4.4.684-692

Stone, C. (1998). Overcoming resistance to technology. The Delta Kappa Gamma Bulletin, 64(2), 15-19.

The General Authority for Statistics. (2020). GaStat: (2.9\%) of Saudi population have disability with (extreme) difficulty. Retrieved from https://www.stats.gov.sa/ar/news/230

The Masters in Special Education Degree Program Guide. (2020). 5 Popular Assistive Software Programs for Special Education. Retrieved from https://www.masters-in-special-education.com/lists/5-popular-assistive-software-programs-for-special-educ ation/

Timucin, M. (2006). Implementing CALL in an EFL context. ELT Journal, 60(3), 262-271. https://doi.org/10.1093/elt/cc1006

Tinio, V. (2002). Survey of information \& communication technology utilization in Philippine public high schools preliminary findings. Retrieved from http://www.fit-ed.org/downloads/ICT\%20Utilization\%20Survey.pdf

Vrasidas, C., \& McIsaac, M. (2010). Integrating technology in teaching and teacher education: Implications for policy and curriculum reform. Educational Media International, 38, 127-132. https://doi.org/10.1080/09523980110041944

Wartella, E., Schomburg, R., Lauricella, A., Robb, M., \& Flynn, R. (2010). Technology in the lives of teachers and classrooms: Survey of classroom teachers and family childcare providers. Retrieved from http://www.fredrogerscenter.org/media/resources/TechInTheLivesofTeachers.pdf

Weiss, M. J. (2002). Hardiness and social support as predictors of stress in mothers of typical children, children with autism, and children with mental retardation. Autism, 6(1), 115-130. https://doi.org/10.1177/1362361302006001009

Williams, P., Jamali, H. R., \& Nicholas, D. (2006). Using ICT with people with special education needs: What the literature tells us. ASLIB PROCEEDINGS, 58(4), 330-345. https://doi.org/10.1108/00012530610687704

Wright, P., \& Macrow, A. (2006, September 6-9). Integrating ICT in pre-service teacher education: Reframing teacher education. In British Educational Research Association Annual Conference, University of Warwick. Retrieved from http://www.leeds.ac.uk/educol/documents/168675.htm

Yvonne, L., \& Lawrence, G. (2010). Teacher-student role redefinition during a computer-based second language project: Are computers catalysts for empowering change? Computer Assisted Language Learning, 15(3), 295-315. https://doi.org/10.1076/call.15.3.295.8185

Zhao, Y. (Ed.). (2003). What teachers should know about technology: Perspectives and practices. Greenwich, CT: Information Age Publishing.

\section{Note}

Note 1 . The two authors contributed equally to this research and they considered as first authors.

\section{Copyrights}

Copyright for this article is retained by the author(s), with first publication rights granted to the journal.

This is an open-access article distributed under the terms and conditions of the Creative Commons Attribution license (http://creativecommons.org/licenses/by/4.0/). 